\title{
Consumer's Buying Behaviour of Motorcycles in Janakpurdham
}

\author{
Dr. Binod Shah \\ Associate Professor \\ Faculty of Management \\ R. R. M. Campus, Janakpurdham, TU, Nepal \\ binodsah.rrc@gmail.com
}

\begin{abstract}
The paper states the review of the factors that influence consumer buying behaviour of motorcycles in Janakpurdham. The focus of the article is in the area of consumer behaviour that plays a vital role in making decisions to purchase any product. The main objective of this study is to examine the factors that influence buying behaviour of consumers to purchase motorcycles. In this study, the questionnaire method is used to collect data. The study has been done by non-probable convenient sampling method. The main finding of this study is that the male folk play a dominant role in influencing the purchase of motorcycles. Servicemen prefer motorcycles in comparison of professionals, businessman and others. Income of consumer plays an important role in the consumer buying decision of motorcycles. Price is the most important factor that influences consumer buying behaviour followed by quality. Also promotion plays a major role in influencing the consumer buying behaviour. This study is important to understand the buying behaviour of consumers.

Keywords: consumer behaviour, demographic factors, psychological factors, marketing factors.
\end{abstract}

\section{Introduction}

\section{Background}

People buy things to satisfy two basic needs physical or material and psychological or mental. The buying decision is influenced by these two basic factors in various combinations, of course along with certain other external factors. Persons buying the same product may have different reasons to do so and persons having same reasons may buy different products. The study of these physical and psychological factors along with various other factors that influence the consumer to make a buying decision is therefore of utmost important for marketers and these constitute the subject matter of consumer behaviour. The field of consumer buying behaviour studies how individuals, groups and organisations select, buy, use and dispose of goods, services, ideas or experiences to satisfy their needs and desires. Understanding consumer behaviour and "Knowing Customers" is never simple. Customer may say one but do another. Schiffman \& Kanuk (1991) stated that consumer'sbehaviour is the study of how individuals 
make decisions to spend their valuable resources (time, money, effort) on consumption related items. It includes the study of what, why, when, where and how often they purchase and how they use the purchased product. Mowen (1993) explained consumer behaviour as the study of the buying units and the exchange processes involved in acquiring, consuming and disposing of goods, services, experiences and ideas. Kotler, Kellev, Koshy \& Jha (2007)stated that a consumer's buying behaviour is influenced by cultural, social and personal factors. Cultural factors exert the broadest and deepest influence. In the study conducted by Khaniwale (2015) about consumer behaviour, he said that both external and internal factors have significant influence on consumer's behaviour which impacts their purchasing process and decision. Consumer's behaviour is affected by a host of variables ranging from personal, professional needs, attitudes and values, personality characteristics, social, economic and cultural background, age, gender, professional status to social influences of various kinds exerted a family, friends, colleagues and society as a whole.

Motorcycles have become a basic requirement for mobility in Nepal due to its poor public transport infrastructure. Along with the easy financing facilities for motorcycles in the country and problems related to traffic and parking, the demand for motorcycles has increased manifolds in the Nepalese market. According to Department of Transport Management, total registration of vehicles in the country was recorded 4,37,614 in 2017-18. Of the total number of vehicles registered in the country so far, 3,41,623 are just motorcycles (www.dotm.gov.np). The motorcycles constitute $78 \%$ of the number of units of all the vehicles sold in 2017-18. A total of 267,439 motorcycles and scooters were registered in 2015-16 and 196,383 motorcycles were registered in 2014-2015.The motorcycle industry has reached the state of a competitive market with a few companies producing a good range of products and present trust is upon innovations and high efficiencies. The market has steadily moved from a seller's market to a buyer's market. The companies are responding quickly to changing customer demands to stay in the business. The rapid growth of middle class section is the primary reason for the growth of motorcycle industry. People in rural and semi-urban areas are trying to elevate their life style and people in urban areas are completely disappointed with the public transport system. The manufacturers of motorcycles distinguish their products on the basis of power, fuel, efficiency and maintenance requirement, easy in handling, style and price. The major players in the motorcycle market are Bajaj Auto Ltd, TVS Suzuki, Hero, Honda, Escorts Yamaha and Royal Enfield.

\section{Research Problems}

Buying decision is a crucial problem. There are established theories in consumer behaviour of decision making. However, today consumer behaviour is highly influenced by behaviour factors. The decision making has become irrational. This study tries to seek the answers of following questions: 
- What are the factors that influence buying behaviour of consumers of motorcycles in Janakpurdham?

- What are the sources of information that induce the consumers to purchase motorcycles in Janakpurdham?

- What are the reasons of purchasing motorcycles of consumers of Janakpurdham?

\section{Research Objectives}

The main objective of the article is to to facus the factors that influence consumer buying behaviour of motorcycles in Janakpurdham. The specific purposes are:

- To assess various factors that influence buying behaviour of consumers of motorcycles in Janakpurdham.

- To assess the sources of information that induces the consumers to purchase motorcycles in Janakpurdham.

- To ascertain the reasons of purchasing motorcycles of consumers of Janakpurdham.

\section{Significance of the Study}

The study would be of very great use to understand the buying behaviour of consumers to buy any product. It would be important to understand the role played by consumers for overall development of consumer market. It would pave the way for the growth of similar studies in the area of buying behaviour of consumers. It would create awareness among the companies about the role and importance of consumer in purchasing decisions. It can be used as a basis for numerous scientific and innovative studies on buying behaviour of consumers in the days ahead.

\section{Limitations of the Study}

The present study is subject to following limitations and constraints:

- It is quite possible that the personal bias of the sample selected may affect the findings.

- The study is confined to the selected respondents from Janakpurdham. The observations of the study of the sample may be different from the other consumers who are not covered by the sample.

- The study could suffer from the problem of non-response bias.

- Consumers are inclined to disclose true information about their purchasing of motorcycles.

- The questionnaires may be mis-interpreted by the consumers and therefore, the required information may not come out. 


\section{Literature Review}

A literature review surveys books, scholarly articles and any others sources relevant to a particular issue, area of research or theory, and by so doing, provides a description, summary and critical evaluation of these works in relation to the research problem being investigated. They are designed to provide an overview of sources you have explored while researching a particular topic and to demonstrate to your readers how your research fits within a larger field of study.

Sathish \& Pughazhendi (2011) expressed that the study is being carried out to understand the customer behaviour of automobile products two wheeler. The objective of the study is to find out the consumer behaviour of automobile products in terms of their buying decisions motives in the two wheeler segment.. It was found that consumers prefer two wheeler because of its utility and easy handling in the heavy rough traffic.

Mani \& Tripathy (2013) focused in his study that the study is based to identify the factors that influence the consumer buying behaviour of the two wheeler bikes at Allahabad, Lucknow and Varanasi cities of Uttar Pradesh, India. The objective of the study is to analyze the impact of behavioural factors of consumers on choosing particular brand. It was found that price, design, mileage, speeds and after sales service are the main factors that influence the choosing a particular brand. Shukla (2016) stated the study concluded that the brand wise has significant difference in customer's perception towards brand image loyalty for the different types of brands of two wheeler. However, there is no significant difference observed in satisfaction level of customers to their owned brand of the wheelers.

Tekin, Yitay and Ayaz, (2016) stated that the study analyses the brand image role on consumer purchasing behaviour from a consumer's perspective. This study found many factors strongly influence the brand image of consumer buying behaviour like social, personal, psychological and cultural factors. Kumar (2017) argued the study concluded that the key factor capable to attract the consumers attention towards the purchase of motorcycle were speed, look, image, price and mileage of motorcycle. Singh \& Verma, (2017) in his study is to look at the factors influencing towards natural nourishments. For this study, information were gathered from 611 Indian buyers through a poll.

Shanmugapriya \& Sangeetha (2018) plead that the objective of the study is to know the socio-economic profile of sample users and to identify customer's opinion level of luxury bikes. It was found that age, gender, marital status, education, income level and occupation are the main determinants to purchase luxury bikes.

\section{Methods and Materials}

The study tries to find out the factors that influence the buying behaviour of consumers of motorcycles in Janakpurdham. The study focuses on understanding the consumers buying 
behaviour based on demographic factors, marketing factors and psychological factors. This section of the paper discusses the research design adopted for the study, types of data used in the study, sample size and data analysis tools.

\section{Research Design}

The descriptive research design has been used to analyse and study the buying behaviour of consumers.

\section{Types of Data}

Both primary and secondary data have been used. The primary data required for the study has been collected by conducting a survey through questionnaire and personal interview. The secondary data required for the study has been obtained through internet, journals, books and websites.

\section{Sample Size}

A total of 100 customers were randomly selected from Janakpurdham for data collection. It was observed that 20 questionnaires were incomplete. They were deleted which gave a sample of 80 respondents in total and samples were taken from motorcycle owners.

\section{Data Analysis Tools}

The collected data from questionnaire are tabled and frequency distribution table is prepared. The frequency distribution is converted into percentage. Frequency and percentage have been used to interpret the data collected. The investigator does not want to consider any other tools for further interpretation.

\section{Results and Discussion}

The buying behaviour of consumers is basically influenced by three major factors, namely, demographic factors, marketing factors and psychological factors. It is these factors that influence the consumer's behaviour while purchasing the product.

\section{Demographic Factors}

There are a number of demographic factors that influence buying behaviour like age, gender, occupation, income etc. A detailed analysis has been conducted on the following factors with respect to demography. 
Table 1

Age of respondents

\begin{tabular}{lcc}
\hline Age & Frequency & Percentage \\
\hline Upto 30 years & 32 & 40 \\
30-40 years & 28 & 35 \\
40-50 years & 15 & 18.75 \\
Above 50 years & 5 & 6.25 \\
\hline \multicolumn{1}{c}{ Total } & 80 & 100 \\
\hline
\end{tabular}

Source. Field survey, 2019.

The table one depicts that out of 80 respondents, $40 \%$ belong upto 30 years age group, $35 \%$ belong to $30-40$ years age group, $18.75 \%$ belong to between $40-50$ years age group and the rest $6.25 \%$ belong to above 50 years age group. Thus, it is concluded that most of motorcycle holders belong upto 30 years age group. The distribution of age group helps to understand the nature, structure, life-style and ultimately the buying behaviour of respondents.

Table 2

Gender of respondents

\begin{tabular}{lccc}
\hline Gender & Frequency & Percentage \\
\hline Male & 74 & 92.50 \\
Female & & 6 & 7.50 \\
& Total & 80 & 100 \\
\hline
\end{tabular}

Source. Field survey, 2019.

It is observed from the table two that out of the 80 respondents, $92.5 \%$ are male and the rest $7.5 \%$ are female. Hence, it is concluded that majority of the respondents are male. It is observed that the male exercise more impact while understanding the buying behaviour of motorcycles than female. 
Table 3

Occupation of respondents

\begin{tabular}{|c|c|c|}
\hline Occupation & Frequency & Percentage \\
\hline Service & 36 & 45 \\
\hline Professional & 20 & 25 \\
\hline Business & 14 & 17.50 \\
\hline Others & 10 & 12.50 \\
\hline Total & 80 & 100 \\
\hline
\end{tabular}

Source. Field survey, 2019.

It is found from the table three that out of 80 respondents, $45 \%$ are service holders; $25 \%$ of the respondents are professional; $17.5 \%$ are businessmen and rest are others. Thus, it is clear from the above analysis that the respondents who are in service are purchasing motorcycles rather than others.

Table 4

Annual income of respondents

\begin{tabular}{lcc}
\hline Annual Income & Frequency & Percentage \\
\hline Below Rs 200,000 & 12 & 15 \\
Rs. 200,000-Rs. 300,000 & 18 & 22.50 \\
Rs. 300,000-Rs. 400,000 & 35 & 43.75 \\
Above Rs. 400,000 & 15 & 18.75 \\
\hline \multicolumn{1}{c}{ Total } & 80 & 100 \\
\hline
\end{tabular}

Source. Field survey, 2019.

It is found from table four that out of 80 respondents, $15 \%$ respondents annual earnings is below Rs 200,000, 22.5\% respondents annual earning is between Rs 200,000 - Rs 300,000 ; $43.75 \%$ respondents annual earnings is between Rs 300,000 - Rs 400,000 and $18.75 \%$ respondents annual earnings is above Rs 400,000 . Hence, it is said that most of the respondents annual earnings between is Rs 300,000 to Rs 400,000 . 
Table 5

Source of awareness

\begin{tabular}{lcc}
\hline Source of awareness & Frequency & Percentage \\
\hline Self & 6 & 7.50 \\
Family members/ relatives & 29 & 36.25 \\
Colleague & 15 & 18.75 \\
Neighbours/ friends & 10 & 12.50 \\
Advertisement & 20 & 25.00 \\
\hline \multicolumn{1}{c}{ Total } & 80 & 100 \\
\hline
\end{tabular}

Source. Field survey, 2019.

It is observed from the table five that out of total 80 respondents, $7.5 \%$ came to know about motorcycle through their self, $36.25 \%$ came to know through their family members/ relatives, $18.75 \%$ came to know through colleagues, $12.5 \%$ came to know through neighbours and friends and $25 \%$ came to know through advertisement. Thus, it is said that most of the respondents came to know about motorcycles through their family members / relatives.

\section{Marketing Factors}

There are a number of marketing factors like product features, promotion, price, brand etc that influence consumer buying behaviour. A few factors are analysed in the below study:

Table 6

Factors considered

\begin{tabular}{lcc}
\hline \multicolumn{1}{c}{ Factors considered } & Frequency & Percentage \\
\hline Features & 9 & 11.25 \\
Quality & 27 & 33.75 \\
Performance & 38 & 47.50 \\
After sales service & 6 & 7.50 \\
\hline \multicolumn{1}{c}{ Total } & 80 & 100 \\
\hline
\end{tabular}

Source. Field survey, 2019.

The table six depicts that out of 80 respondents, 9 respondents have given preference to features which comes to $11.25 \% .27$ respondents have given preference to quality which comes to $33.75 \%$. 38 respondents have given preference to performance which comes to $47.5 \%$ and 6 respondents have given response to after sales service which comes to $7.5 \%$. Thus, it is observed that most of respondents consider performance factor while purchasing motorcycles. 
Table 7

Price, quality and brand

\begin{tabular}{|c|c|c|}
\hline Price, quality and brand & Frequency & Percentage \\
\hline Price & 45 & 56.25 \\
\hline Quality & 22 & 27.50 \\
\hline Brand name & 13 & 16.25 \\
\hline Total & 80 & 100 \\
\hline
\end{tabular}

Source. Field survey, 2019.

The table seven reveals that the price and the quality have been given importance by the respondents. In price category, 45 persons have been responded which comes to $56.25 \%$. In quality category, 22 persons have been responded which comes to $27.50 \%$. In brand name category, 13 persons have been responded which comes to $16.25 \%$.

Table 8

Brand loyalty

\begin{tabular}{lccc}
\hline & Brand loyalty & Frequency & Percentage \\
Yes & & 62 & 77.50 \\
No & & 18 & 22.50 \\
\hline & Total & 80 & 100 \\
\hline
\end{tabular}

Source. Field survey, 2019.

The table eight reveals that the large numbers of respondents are brand loyal. They have considered brand while purchasing motorcycles. 62 respondents have given positive response to the brand. They have answered yes they are brand loyal and it is $77.50 \% .18$ respondents have not considered the brand of motorcycles while purchasing motorcycles. It is $22.50 \%$.

\section{Psychological Factors}

The buying behviour of consumers is influenced by a number of internal or psychological factors likes buying motives, perception of the product and attitudes towards the product. Here, reasons for purchasing motorcycles and time taken to decide for purchasing motorcycles are analysed:

Reasons for purchasing motorcycles. Motivation acts as a driving force that impels an individual to take action to satisfy his needs. There may be various reasons for purchasing motorcycles. Some important reasons are convenience, entertainment, replacement, fashion etc. 
Table 9

Reasons for purchasing motorcycles

\begin{tabular}{lcc}
\hline \multicolumn{1}{c}{ Reasons } & Frequency & Percentage \\
\hline Convenience & 44 & 55 \\
Entertainment & 2 & 2.50 \\
Replacement & 19 & 23.75 \\
Due to fashion & 15 & 18.75 \\
\hline \multicolumn{1}{c}{ Total } & 80 & 100 \\
\hline
\end{tabular}

Source. Field survey, 2019.

The table nine reveals that the reasons mentioned by the respondents why motorcycle was necessary to them. Out of 80 respondents, 44 respondents have considered suitability of motorcycles because it is very convenient to them. It means it is more convenient and needed to them for saving the time and reaching on time at the place of destination. 19 respondents have responded for replacement. It is $23.75 \%$. Replacement of old motorcycle is made because it was not functioning properly and frequently required repairs. The fashion is also considered important by 15 respondents and it is $18.75 \%$. The respondents from higher income group and youths have responded for purchasing motorcycle as a fashion and as a symbol of status for them.

Time taken to decide for purchasing motorcycles. People of Janakpurdham have religious belief and faith on certain matter for purchasing motorcycles. Some consumer may try to know the suitable day for purchasing i.e. Muhurta. On good muhurta, they decide to purchase. Therefore, they wait for suitable time or Muhurta. Whatever may be the belief or reasons, time is required for purchasing motorcycles.

Table 10

Time taken to decide for purchasing motorcycles

\begin{tabular}{lcc}
\hline Time taken & Frequency & Percentage \\
Less than one week & 15 & 18.75 \\
\hline Two weeks & 11 & 13.75 \\
One month & 24 & 30 \\
Two months & 12 & 15 \\
Three months & 7 & 8.75 \\
More than three months & 11 & 13.75 \\
\hline \multicolumn{1}{c}{ Total } & 80 & 100 \\
\hline
\end{tabular}

Source. Field survey, 2019. 
The table ten indicates the time taken for purchasing motorcycles. 15 persons have taken less than one week for purchasing motorcycles. It is $18.75 \% .11$ persons have taken two weeks for purchasing motorcycles. It is $13.75 \%$. Majority of respondents have taken one month. 24 persons have taken one month for purchasing motorcycles. It is $30 \% .12$ persons have taken two months for purchasing motorcycles which is $15 \% .7$ respondents have taken three months for purchasing motorcycles and their percentage is 8.75 .11 respondents have taken more than three months to purchase motorcycles and their percentage is 13.75 .

\section{Findings}

- There are a number of factors that influence consumer buying behaviour. This includes demographic factors like age, income, gender, occupation etc; marketing factors like product features, price, brand, quality etc and psychological factors like convenience, fashion, time taken etc.

- According to the analysis, the male population of Janakpurdham is purchasing more motorcycles than female. It is also proved that the male folk play a dominant role in influencing the purchase of motorcycles.

- Servicemen prefer motorcycles in comparison to professionals, businessman and others.

- Income plays an important role in the consumer buying decision of motorcycles.

- Price is the most important factors that influence consumer buying behaviour followed by quality.

- Consumers are most influenced by the convenience aspect of the motorcycles. This is the most important reason for which consumers purchase motorcycles.

\section{Conclusion}

The motorcycle has now become one of the most popular modes of transportation among Nepalese middle class families because it is cost effective, economical and easy to navigate through the traffic. The study of consumer behaviour is quite complex because of many variables involved and their tendency to interact with and influence each other and the buyer. Consumer behaviour plays a major role in making decisions to purchase any product. There are a number of factors that influence consumer buying behaviour. Demographic factors like age, income, gender, occupation etc; marketing factors like product feature, price, quality, brand etc and psychological factors like convenience, fashion, time taken etc are the major factors that influence the consumer behaviour while purchasing motorcycles. Consumers mainly come to know about motorcycles through family members / relatives, advertisement and colleagues. The main reason for purchasing motorcycles is convenience. 


\section{Implications}

- Buying behaviour of consumers is very complex. Therefore, it is essential for the marketers to understand and study the buying behaviour of consumers.

- Consumers should not only focus on the financial aspect of motorcycles but also take into consideration the quality, after sales service etc.

- Consumers should not only rely on advertisement as an important source of information but also collect information from other sources.

- It has been proved that male populations of Janakpurdham are using motorcycles more than the female population. Therefore, female population should also be encouraged to purchase motorcycles.

- The marketers should also introduce schemes for lower and middle income groups so that they also will be in a position to purchase motorcycles.

\section{References}

Khaniwale, M. (2015). Consumer buying behaviour. International journal of innovation and scientific research; Vol 14, issue 2, p. 278-286

Kotler, P., Keller, Koshy K.L., A. \& Jha, M. (2007). Marketing management.12th edition. United States. Person Education.

Kumr, S. (2017). Consumer behaviour towards motorcycle. International Journal of Research: Vol. 1, p. 345-348.

Mani, R. \& Tripathy, D. (2013). A study on consumer buying behaviour towards two wheeler bikes in context to Indian Market. International Journal of Advanced Research in Management: Vol. 4, Issue- 1, p. 65-73.

Mowen, J.C. (1993). Consumer behaviour. Third Edition. New York: Macmillan Publishing Company.

Sathish M. \& Pughazhendi, A. (2011). A study on consumer behaviour of automobile products with special reference to two wheeler in Tirunelveli city, Tamil Nadu, India. Indian Journal of Applied Research: Vol. 1, Issue - 3, p. 161-163.

Schiffman, L.G. \& Kanuk, L. L. (1991). Consumer behaviour. Fourth Edition. London: Prentice Hall International.

Shanmugapriya, S. \& Sangeetha, M. (2018). A study on determinants of buying behaviour on luxury bikes with special references to Pollachi Taluk. Universal review: Vol. 7, Issue XII, p. 1596-1607. 
Shukla, R.K. (2016). Measuring brand power through brand image and customers satisfaction of two wheeler automobile industry. International research journal: Vol 6, p. 134-141.

Singh, A. \& Verma, P. (2017). Factors influencing Indian consumer's actual buying behaviour towards organic foods products. International Journal of Marketing Research: Vol 167, P.No. 473-483.

Tekin, G.; Yitay, S. \& Ayaz, E. (2016). The effects of brand image a consumer buying. International Journal of Academic Value Studies: Vol. 2, Issue-1, P. No. 1-24.

\section{Appendix}

\section{Questionnaires}

1. Name (Optional):

2. Address: (Optical):

Note: Please tick the suitable answer.

3. Age:
(a) upto $30 \mathrm{hrs}$
(b) 30-40 years
(c) 40-50 years
(d) 50 years

4. Sex:
(a) Male
(b) Female

5. Occupation
(a) Service
(b) Business
(c) Professional
(d) Others

6. What is your annual income?
(a) Below Rs 200,000
(b) Rs 200,000-Rs. 300,000
(c) Rs 300,000-Rs 400,000
(d) Above Rs 400,000

7. From which sources do you come to know about motorcycles?
(a) Myself
(b)Family/ members/ relatives
(c) Colleagues
(d) Neighbours \& Friends

8. What factors do you consider while purchasing motorcycles?
(a) Features
(b) Quality
(c) Performance
(d) After sales service

9. Which factors is considered important while purchasing motorcycles?
(a) Price
(b) Quality
(c) Brand name

10. Are you brand loyal?
(a) Yes
(b) No

11. Why do you purchase motorcycles?
(a) Convenience
(b) Entertainment
(c) Replacement of old vehicles
(d) Fashion

12. How much time is taken to purchase motorcycles?
(a) Less than one week
(b) Two weeks
(c) One month
(e) Three months
(d) Two months
(f) More than three months 